\title{
The Concept of an "Islamic State" and Its Applicability in the 21st Century: An Appraisal of Muhammad Asad's Model
}

\author{
Showkat Ahmad Dar*
}

\section{Introduction}

With the evolution of statecraft in the West and before Kemal Ataturk's abolition of the caliphate (khiläfah) in 1924, pro-Islamic scholars worldwide endeavored to formulate a political system that would be in conformity with the Shariah's norms. The reactions to the conspiracies against the caliphate and the Muslim world's fragmentation into nationstates were witnessed throughout the Muslim world, but especially in Egypt and the Indian subcontinent. Abul Kalam Azad (1888-1958) was the first person from the Indian subcontinent to take up this concept. He wrote Mas'alah Khiläfah (The Issue of the Caliphate, 1920), disseminated his ideas through his magazines al-Hilal and al-Balägh and founded the organization Hizbullah to establish God's kingdom on Earth (Hukūmat-e-llähiyyah). This was followed by the Khilāfah Movement (1919-1924), which sought to restore the caliphate.

Syed Abul Ala Mawdudi (1903-1979), whose political activities and writings have influenced the Muslim world profoundly, resolved to continue his mission. Working by himself for almost seven years as a journalist, he presented a methodology for establishing God's kingdom and reviving Islam as a complete way of life. In order to realize his goal, in 1941 he founded the Jamā'at-e-Islāmī movement (Ahmad, 2004, 71). In Egypt, Muhammad Rashid Rida (1865-1935) was the first person to write a book in which he called for restoring the caliphate: Al-Khiläfah aw al-Imāmah al-'Uzmā (The Caliphate or the Supreme Imamate, 1923). He was followed by Hasan al-Banna (1906-1949), who used Rida's proposed model to achieve its goal of establishing an Islamic state in Egypt. To actualize this cause, he established Al-Ikhwān Al-Muslimūn (the Muslim Brotherhood) in 1928, a movement that remains active throughout Muslim world. Various circumstances lead al-Banna to work for a true "Islamic government" (Belkeziz, 2009, 120). He used to say:

The Muslim Brotherhood believes that the Khiläfah is the symbol of Islamic unity, and a feature for the connection of Islamic states; it is an Islamic ritual that Muslims contemplate and in which they should take an interest. [... It] is the Muslims' duty to think of the issue of their Khiläfah from the times when it was distorted, passing through the times when it was revoked, and up to now (Belkeziz, 2009, 137-38).

\footnotetext{
Ph.D. Research Scholar, Aligarh Muslim University (AMU), Department of Islamic Studies. Correspondence: ashiqsir786@gmail.com. Address: Aligarh, Uttar Pradesh, India-202002.
} 
After the mid-twentieth century, all Islamic activists and religious organizations wanted to set up the best possible state, namely, one that works in consonance with the Creator's laws and seeks to attain the greatest good for the most people (Ghazi, 1956, 5). Some Muslim thinkers, however, held that the people's welfare could be achieved by separating politics from religion. The pioneer of this thought was Ali Abd al-Raziq, a contemporary of Rashid Rida and author of al-Isläm wa Ușül al-Hukm (Islam and the Principles of Governance, 1925).

Scholars who are exploring the character of an Islamic state and its applicability in the modern era can be classified into two groups: proponents of the Shariah and proponents of the secular state (Hasan, 1998, 105-109). Mainstream political thinkers of Islam, namely, proponents of the Shariah, posit that when everything is analyzed and interpreted politically and economically, government and politics have a profound impact upon the people's life. Thus, Allah could not have excluded such a critical subject from His guidance and let humanity do as it wished in these spheres of life. Thus, a distinct Islamic model exists and its immediate application is mandatory. To achieve this goal, they gave preference not necessarily to aggression, but rather to purely Islamic methods that are in conformity with the teachings of the Qur'an and Sunnah.

With the advent of twenty-first century, the concept of an Islamic state continues to face many challenges. Events like 9/11 and other terror attacks, as well as the emergence of ISIS, have played a crucial role in how people perceive an Islamic state and even Islam itself. For example, is an Islamic state one of terror? What makes a state an Islamic, what determines its "Islamicness" and what characteristics are required? These and other questions need to be addressed. Keeping all of this in mind, the present study focuses on how Muhammad Asad (1900-1992), the writer, adventurer, diplomat, Muslim thinker par excellence, translator and exegete of the holy Qur'an, viewed this concept. His political ideas came to fore when Indian Muslims were struggling for a separate homeland.

Due to his keen desire for the Muslims' cultural, intellectual, political and spiritual renaissance, he immersed himself fully in Islam's basic sources, namely, the Qur'an and the traditions of the Prophet, and studied Islam's history by reading the available literature, whether positive or negative (Asad, 1934, 11). He travelled in the Muslim world and remained close to government officials, which helped him understand how these countries were administered. Moreover, he actively supported Libya's Sanusi movement (active since 1911), which sought his help as a policymaker in their struggle against imperialistic Italy (Asad, 1954, 333ff), took part in creating Pakistan and wrote about why it was created (Asad, 1987, 71-81). Thus, he formulated his views in a concrete political situation of a struggling state whose raison d'être was Islam and the desire of the majority of Indian Muslims to have their own state where they could live as Muslims (Rosenthal, 1965, 125).

\section{Asad's Position in Islamic Political Thought}

It is difficult to classify such scholars into groups, for the concepts by which they are being classified bear different meanings. Leonard Binder classifies them into traditionalists, modernists, fundamentalists and secularists (Binder, 1963, 116); John L. Esposito divides them into secularists, rejectionists, extremists, conservatives and reformers/reformists (Esposito, 
2001, 145); and Pipip Ahmad Rifai Hasan limited this classification to two: proponents of a Shariah state and proponents of a secular state (Hasan, 1998, 108). Hasan maintains that Asad belongs to the modernist camp of the Shariah state proponents, which assumes that Islam sanctions such a state grounded on Shariah principles but leaves some room for contemporary human discretion as to the Shariah's interpretation and application (Ibid.).

\section{Asad's Concept of an Islamic State}

Without engaging himself in hair-splitting debate over an Islamic state, Asad deliberates over its essence. Regardless of what it is (e.g., khiläfah or imämah), he views it as a coordinating agency with the powers of command and prohibitiont (Asad, 1961:4) and a tool by which Islam's ideals can be brought to practical fruition (Ibid., 96). He argues that Islam expects Muslims to strive, at all times and under all circumstances, for an Islamic state because Islam's basic teachings not only circumscribe humanity's relation to Allah, but also lay down a definite scheme of social behavior to be adopted (Ibid., 2). Kalim Siddique made the same observations at a later date when he argued that an "Islamic state is the Muslims' natural habitat and their dependence on the Islamic state is as complete as that of fish on water" (Siddique, 1983, 9). By identifying an Islamic state as the chief instrument of Divine purpose on Earth (Ibid.), he stated that there are only two options for Muslims: to live in an Islamic state or to struggle to establish one. To quote him verbatim:

It is almost impossible to be a Muslim without either living in an Islamic state or being engaged in a struggle to establish an Islamic state. If one or other of these conditions is not met, I fear that perhaps the bulk of the Sunnah of Muhammad, upon whom be peace, is ignored. [...] Islam is incomplete without the Islamic State. [...] The Islamic state is Allah's chosen framework in which the moral, political, social, economic and cultural goals of Islam are pursued by the Muslim Ummah. (Siddique, 1986, 2)

Asad also observed that such a state is imperative if Muslims truly want to translate the tenets of Islam into action. These ideas are relevant to Mawdudi who, under the slogan of "Hukümat-e-llāhiyyah," maintained that "the struggle for obtaining control over the organs of the state when motivated by the urge to establish Din and the Islamic Shariahand to enforce the Islamic injunctions is not only permissible but is positively desirable" (Mawdudi, 1990, 177).

Asad rejects the idea of a secular state on the grounds that it does not submit to a universal morality but to the interests of a nation, class, race or some other divisive category. In addition, such states do not have stable norms by which to determine good and evil or right and wrong (Asad, 1961: 4-5). He also held that contemporary Western political systems fail to provide universal order because none of them has ever made a serious attempt to consider political and social problems in the light of absolute moral principles (Ibid., 5-6). While exploring his ideas, it becomes evident that he believes that a religion-based state offers an infinitely better prospect for national happiness than does a state founded upon the concept of a secular political organism. The reasons for this is that the authority derived from religion provides humanity's biological and social needs and makes full allowance for the law of historical and intellectual evolution, to which human society as a whole is subject (Ibid., 7-10). 
He also contends that an Islamic state's outward forms and functions need not necessarily correspond to any historical precedent. In fact, all that such a state has to do is embody, in terms of its constitution and practice, those clear-cut Islamic ordinances that have a direct bearing on the community's social, political and economic life (Asad, 1961, 17). Far from being the only modern Muslim thinker to demand "back to Qur'an and Sunnah" to achieve the renewal of Islam in an Islamic state, he has the merit of analyzing the crucial question of Islamic law's place and scope in clear and simple terms (Rosenthal, 1965, 127). Unlike all of the others, he stresses the need to return to the fundamentals by cutting through the "many layers of conventional and frequently arbitrary interpretation" (Ibid). Curious about how to devise a constitution that would be fully compatible with Islam's two core sources and at the same time viable and relevant (Asad, 1961, ix-x), he encourages the full use of humanity's social and intellectual evolution and rejects the idea that any deviation from the model of the Rightly Guided Caliphs necessarily detracts from a state's Islamic character (Ibid., 22). He criticizes the use of non-Islamic terms to define Islamic concepts and considers their use not only a pitfall for students of Islamic political law, but also a great danger for future developments (Ibid).

Asad agrees with Abd al-Raziq and maintains that the impartial examination of the core sources' political ordinances prove that there is no specific form of state and that Islamic law elaborates a constitutional theory. Nevertheless, for Asad the political law emerging out of this context is not an illusion, but a very vivid and concrete framework inasmuch as it outlines a political system that can be realized at all times and under all conditions (Asad, 1961, 22-23). Based on these views, he maintains that the Muslims of every age are obliged to find the form that best meets their needs. But there is one condition: It must conform with the principles found in the Qur'an and Sunnah (Ibid, 23). In the modern era, a time when political thought and its forms have reached their zenith, Asad believes that the presidential form is the most suitable because it corresponds to the Islamic concept of caliphate (Ibid., 61).

\section{The Main Features of Asad's Model of an Islamic State}

\section{All Sovereignty belongs to Almighty Allah}

The discussion regarding sovereignty and the comparison between divine and popular sovereignty are of the first importance in this regard. Like other Islamic state's proponents, Asad holds that an Islamic state's foremost feature is that sovereignty belongs only to Allah, the Real Sovereign of the Worlds. In addition, he asserts that Allah, the Lord of all dominions, is the ultimate source of all moral and political authority (Asad, 1980, 175). While rejecting the "will of people" as the source of state sovereignty, he nevertheless considers the sovereignty exercised by the Muslim community as vicarious sovereignty (Ibid., 174), meaning that their "sovereignty" derives from Allah and not from themselves (Asad, 1961, 37-39). Furthermore, he writes that in a consciously Islamic society the people's consent to a particular governing method and style of sociopolitical cooperation is a result of their 
having accepted Islam as a divine ordinance and their own lack of any sovereignty. Asad thus concludes that an Islamic state, which owes its existence to the will of people, derives its sovereignty from Allah (Ibid.).

\section{The State as the Vicegerent}

Asad maintains that the Muslim community acts as Allah's vicegerent by utilizing its powers in consonance with the Shariah (Asad, 1980, 174) to elect a wise and mature leader who believes in His sovereignty and the law's divine origin (Asad, 1961, 40-42). In his view, the Islamic state can collectively be termed the vicegerent of Allah (Ibid., 34; 83).

\section{Mutual Consultation}

Another essential feature for Asad is that the government's affairs rest on popular consent. Today, the concept of consultation (shūrā) has become an essential one in contemporary political thought. It is on the basis of this term that the Islamic state is considered compatible with modern democratic forms of government. On the basis of amruhum shüra baynahum (Qur'an, 3:159) and other prophetic sayings, Asad asserts that "both the executive and the legislative organs must be established through election" (Asad, 1963, 9; cf. Asad, 1961, 43ff). Along with Tariq Ramadan and others, Asad emphasized its vital role within an ever-evolving ummah. They explain that this process allows Islamic law to evolve sensibly so that it can offer solutions to totally new issues. He therefore states that it caters to the "continuous temporal legislation of our social existence" (Asad, 1961, 43). In general terms, Ramadan describes shūrā as "the space which allows Islam the management of pluralism" (Ramadan, 2004, 81).

\section{Legislation Is Not Repugnant to the Qur'an and Sunnah}

While explaining verse 3:159, he maintains that the injunction amruhum shürä baynahum implies that the government, by consent and council, must be regarded as a fundamental clause of all Qur'anic legislation relating to statecraft (Asad, 1980: 145). The only constraint that he puts on popular consent is that no legislation or decision can be acted upon if they are either partially or totally repugnant to Qur'an and Sunnah. To support his argument, he quotes Qur'an 33:36 and maintains that "the constitution must explicitly lay down that no temporal legislation or administrative ruling, be it mandatory or permissive, shall be valid if it is found to contravene any stipulation of the shari'ah" (Asad, 1961, 35). In addition, he asserts the need for a universal codification of Islamic law so that its ordinances can be enforced in the territories under its jurisdiction. This is rather difficult, due to the numerous conventional schools of Islamic thought. While rejecting the notion of using the fighi teachings to which the majority population adheres, Asad argued that "an Islamic state must have at its disposal a code of the Shariah which (a) would be generally acceptable to all its Muslim citizens without distinction of the fiqihi schools to which they may belong, and (b) would bring out the eternal, unchangeable quality of the Divine Law in such a way as to demonstrate its applicability to all times and all stages of man's social and intellectual development" (Ibid, 101).

\section{Checks and Balances}

Asad opines that there can be no radical separation of a government's legislature (law-making body), executive (director and supervisor of the law's implementation) and judiciary 
(custodian of justice) in Islam (Asad, 1961, 51). While he admires the merits of this separation of powers, as it prevents the executive from exercising its powers in an irresponsible manner (Ibid.), during a time of emergency it can lead to autocratic governance. To avoid such a disadvantage, Islam follows a middle way by integrating the executive and legislative branches in the amir (leader) (Ibid., 52).

The state's organs are checked by the stipulation amruhum shūrā baynahum that, for Asad, means that all governmental activities must be an outcome of consultation among the community's accredited representatives (Ibid.). This, he believed, "could be achieved by (a) restricting the membership of each committee to a very small number, and (b) according to each of the committee the function of an advisory council of the minister (or secretary of state) concerned" (Ibid, 65). In case of disagreement between legislature and executive, "the dispute should be referred to a body of arbitrators [judiciary] who, after an impartial study of the problem, would decide which of the two conflicting views is closer to the spirit of Qur'an and Sunnah" (Ibid., 66). This tribunal should be the guardian of the constitution. This is how Asad deals with different organs of the government of Islamic state.

\section{Guarantor of Rights}

Asad maintains an Islamic state guarantees following rights to its citizens, regardless of their religious affiliation/faith-groups (including atheists and agnostic persons present in the state).

\section{Freedom of Opinion}

The right to free expression of one's opinions in speech and in writing is a fundamental right of all citizens (Asad, 1961, 81-83) However, he does lay down some restrictions: "freedom of expression must not be used for incitement against the law of Islam or sedition against the established government, and must not be allowed to offend against common decency" (Ibid., 83).

\section{Protection of the Citizens}

Asad states that one of the state's fundamental duties is to protect its citizens against external and internal enemies (Asad, 1961, 84) and that this duty is not limited to the tangible factors of existence but extends to their dignity, honor and privacy (Asad, 1980, 218). He argues that the state must provide socio-economic and political security to all of its citizens and rejects secret police supervision, arrest on mere suspicion and imprisonment without conviction by a duly established court of law, for all of these clearly run counter to this fundamental guarantee (Asad, 1961, 83-86).

\section{Free and Compulsory Education}

The state to is duty-bound to make knowledge freely accessible to every male and female citizen (Asad, 1961, 86-87). In his translation of the Qur'an, he asserts that one goal of social legislation is to provide equal opportunities and facilities for education to every man, woman and child (Asad, 1980, 219).

\section{Socio-Economic Security}

The state is obliged to provide food, cloth and shelter to its citizens so that no person is 
forced to live in poverty (Asad, 1961, 88-91). Asad also argues that many Qur'anic verses lay down a comprehensive social security scheme that has been amplified and explained by many of the Prophet's commandments, such as giving the needy a share in one's wealth so that everyone's socio-economic security is secured (Asad, 1980, 219). The state can facilitate this through zakat and additional taxes on property and revenue (Asad, 1961, 91).

\section{The Status of non-Muslim Citizens}

In an Islamic state, determining each citizen's religious status is a crucial and delicate issue and thus remains a highly debatable and discussed concept even today. Islamic law views non-Muslim citizens as a protected minority (ahl al-dhimmah) (OEIW, 2009, 71-72) who are classified as "inhabitants" or "aliens" (musta'man), Contractees, and Conquered. Islam accords them equal rights, although it views each group as slightly different from the others (Mufti, 2008, 2:542; Maududi, 1960, 278f). They are just like the minorities living in a modern nation-state, with the sole exception that they are classified on the basis of religion while the latter are classified in terms of numbers, for the majority is tasked with policymaking (Maududi, 1960, 272f). Asad believes in the religious classification of citizens of an Islamic state but argues that they are, in general, the people who stand up for the equity and justice and work for the common welfare. Despite the religious difference, Asad holds that there should be mutual toleration among citizens (Asad, 1961, 40).

While refuting the views of those who maintain that an Islamic state discriminates against non-Muslims, Asad maintains that such discrimination relates only to the theory and not the practice of government. He writes:

One must...frankly admit from the outset that without a certain amount of differentiation between Muslim and non-Muslim there can be no question of our ever having an Islamic state or states in the sense envisaged in Qur'ān and Sunnah. Consequently, any prevarication on this subject is utterly dishonest with regard to both the nonMuslim world around us and the Muslim community itself. (Asad, 1961, 40)

He also holds view that this discrimination never implies that non-Muslim citizens should be treated unfairly in the ordinary spheres of life; rather, "they must be accorded all the freedom and protection which a Muslim citizen can legitimately claim" except the position of leadership (Asad, 1961, 40). He emphasizes that Islam's socio-political system seeks justice for each citizen (Ibid., 99), but that only a Muslim can be the head of state (Hasan, 1998 , 142) for (1) a non-Muslim, although having great personal integrity and loyalty to the state, could never work wholeheartedly for Islam's objectives and that, in all fairness, (2) the Muslim citizens could not place such a demand upon him (Asad, 1961, 41; Rosenthal, 1965,129 ). This principle is common in every contemporary ideological organizations (such as Communism, socialism among others), and no one can afford to entrust the direction of its affairs to people who do not share its ideology (lbid). That is why those who believe in democracy never allow anti-democratic person to take the charge of their affairs. It seems that for Asad, a non-Muslim could only become the head of the state by sincerely embracing Islam. 


\section{The Status of Women}

The status of women, in aggregation, is equal to that of men. For the maintenance of human happiness and dignity, the state is responsible for providing citizens with material welfare and economic facilities without any gender-based discrimination (Asad, 1961, 88; Hasan, 1998, 130). All of its resources, as per Asad, must be harnessed to provide an "adequate means of livelihood," and all opportunities should be open equally to all of its citizens so that "no person should enjoy a high standard of living at the expenses of others" (Ibid). Along with the provisions of material well-being for the women, the state must take measures to develop in them a sense of God-consciousness so that they do not abandon it for soul-destroying materialism (Ibid, 90). The state must make sure that "equity prevails within the community, and that every citizen — man, woman and child—shall have enough to eat and to wear, shall be succored in case of illness and have a decent home in which to live (Ibid., 90-91).

However, there is a dispute over whether women in an Islamic state are entitled to political rights and can participate in elections and other related aspects, including serving as head of state. Some argue that women are restricted to household tasks and have no political rights. Others say that they have political rights but cannot serve as head of state or that they have full political rights because religion has nothing to do with politics (Fahad, 2007, 220-221). Keeping these positions in mind, Asad follows the middle way: Islam provides restricted political rights to women.

Pipip Ahmad Rifai Hasan, who analyzed Asad's political thought, maintains that his views on "womens' political participations seem quite liberal" for he mentions "women" explicitly when discussing who can elect members of the legislative assembly and the qualification to become a member of the Majlis al-Shürä (Hasan, 1998, 146). As regards the head of state, he writes that the person should be a Muslim, wise and mature and believe in the divine origin of the Shariah. He does not, however, mention that women are eligible for this post (Asad, 1961, 39-42). But contrary to the analysis of Rifai Hasan, his methodology evinces that he disagreed with those who held that a woman can be the head of state. His aim was to discern an outline of an constitution on the strength of Islam's clear-cut injunctions (Ibid., xi). The Qur'an and authentic traditions negate this possibility. The Qur'an claims: "men shall take full care of women" (4:32) and it is mentioned in a prophetic saying that:

$$
\text { لمن عنلح قوم ولو المر م امرا }
$$

A nation that hands its affairs over to a woman will not prosper. (Bukhari, 4425)

Many Islamic scholars have cited this tradition to bolster their claim that women cannot serve as a head of state, a member of the judiciary, in Parliament or any similar organization and command an army (Fahad, 2007, 225).

\section{Question of Jihad}

Jihad (lit. struggle) is an attempt to bring one's personal and social life into conformity with God's will. However, today it is associated with "fighting in a war," even though the Qur'an uses 
the term qitäl for that aspect. Asad insists that jihad (here fighting in a war) is purely defensive in character. He refers to the following verses that, according to him, forbid a war of aggression:

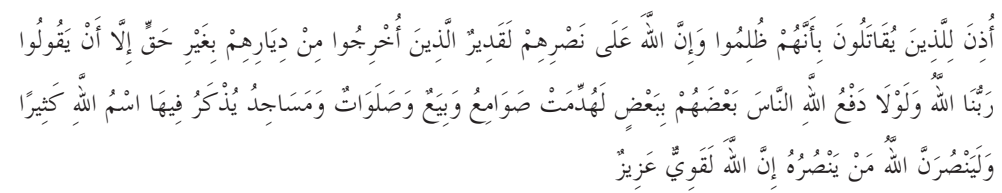

Permission [to fight] is given to those against whom war is being wrongfully waged -and, verily, God has indeed the power to succor them-: those who have been driven from their homelands against all right for no other reason than their saying, "Our Sustainer is God!" For, if God had not enabled people to defend themselves against one another, [all] monasteries and churches and synagogues and mosques - in [all of] which God's name is abundantly extolled-would surely have been destroyed [ere now]. (Qur'an, 22:39-40; Asad, 1980, 703-704)

He opines that this verse is used "extensively to denote a war of defense-defense of man's freedom of religion, of his country and of the liberty of his community" (Asad, 1961, 71) and that all relevant Traditions (quoted, particularly, by Tabari and Ibn Kathir) show that this is the earliest Qur'anic reference to the problem of war as such (Asad, 1980, 704). As regards "cloisters, churches, synagogues and mosques," all mentioned in above verses, that this defensive war is fought on behalf of both the state's Muslim and non-Muslim citizens (Asad, 1961, 71).

Here, Asad advocates jihad when the Islamic state already exists. His contemporaries like Sayyid Qutb, an influential figure who termed it The Neglected Duty, speak of the struggle that goes into establishing an Islamic state (Bowering, 2015, 100). Nevertheless, Asad emphatically holds that Islam not only negates but also forbids its followers to wage a war of aggression (Asad, 1961, 71), for the Holy Qur'an claims:

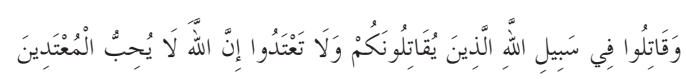

And fight in God's cause against those who wage war against you, but do not commit aggression - for, verily, God does not love aggressors. (Qur'n, 2:190; Asad, 1980, 76)

He says that this verse unequivocally permits Muslims to fight only defensive wars (Asad, $1980,77)$. He further justifies war to eliminate persecution and enable people to freely worship Allah without any fear of persecution and oppression. He quotes the Qur'an as:

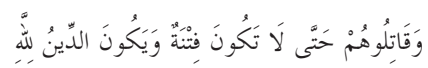

And fight against them until there is no more oppression and all worship is devoted to God alone. (Qur'aan, 2:193; Asad, 1980, 77)

According to Asad, the fundamental principle of self-defense as the only possible justification for war is maintained throughout the Qur'an, along with the fact that Allah permits His believers to be kind and just to those unbelievers who do not wage war against or oppress Muslims:

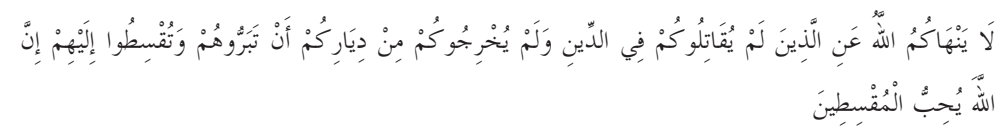


As for such [of the unbelievers] as do not fight against you on account of [your] faith, and neither drive you forth from your homelands, God does not forbid you to show them kindness and to behave towards them with full equity: for, verily, God loves those who act equitably. (Qur'an, 60:8; Asad, 1980, 1163)

After mentioning these verses in his book The Principles of State and Government in Islam, Asad says that these are decisive and self-explanatory Qur'anic ordinances and that all of the Traditions enjoining jihad must be read in the light of them. In other words, it is meant strictly for defensive purposes in which both Muslim and non-Muslim citizens can actively participate. The only difference between them in this case, he writes, is that Muslims are obliged to sacrifice their life, while non-Muslims are not but can choose to do so to defend the state. In addition, they do not have to fight if doing so violates their conscience, in which case they must pay the jizya, unless, according to Asad (1961, 72-75; Asad, 1980, 362), they are women, men who have not yet reached full maturity, elderly men, the sick and crippled, the destitute, priests and monks, and all men who choose to render military service.

He also asserts that Muslims can refuse to fight if their government launches a war of aggression under the pretext of jihad on the basis of the following prophetic saying:

$$
\text { لا طاعل فى معصى }
$$

No obedience is due in sinful matters: behold, obedience is due only in the way of righteousness. (Asad, 1961, 76)

\section{Purpose of the State}

Asad writes that the ultimate purpose of an Islamic state is to provide a political framework for Muslim unity and cooperation (1961: 30) Thus it is not a goal or an end in itself, but only a means. The goal is the growth of a community of people who work to create and maintain those social conditions that would enable the greatest number of people to live, morally as well as physically, in accordance with Islam, the natural Law of Allah (Ibid., 30ff). He maintains that Muslims should strive to establish such a state in order to:

1. Enforce Shariah as the supreme law of the land so that that equity may prevail (1961: $1-3,51-56)$

2. Confirm the relation of the creature with their Creator (Ibid., 2)

3. Invalidate all laws repugnant to the Qur'an and Sunnah (Ibid., 35)

4. Enforce the ordinances of the Shariah in the territories under its jurisdiction (Ibid., 34)

5. Create unity and brotherhood [and sisterhood] among Muslims based on common ideological consciousness (Ibid., 30-31)

6. Conduct all affairs through consultation, because dictatorship is contrary to Islam (Ibid., 51-56)

7. Arrange social and economic relations in such a way that every individual lives in freedom and dignity and people feel safe and protected (Ibid., 87) 
8. Enable all Muslims to realize Islam's ethical goals not only in their beliefs, but also in the practical sphere of their lives (Ibid., 33)

9. Ensure to all non-Muslim citizens complete physical security as well as complete freedom of religion, of culture and of social development (Ibid.)

10. Prevent injustice and establish justice on Earth (Ibid.)

11. Defend the country against attack from without and disruption from within; and

12. Propagate Islam's teachings to the world at large (lbid.)

\section{Applicability in the 21 st Century}

Today, it seems that establishing an Islamic state is impossible. The changing political atmosphere in the Muslim world, especially after 9/11, the American invasion and occupation of Iraq and Afghanistan, and the Arab Spring and its aftermath, has caused Muslims to find democracy more attractive. On the other hand, Islamic movements are aspiring to establish an Islamic state. No Muslim country has recognized or even officially supported the claim of Islamic State of Iraq and Sham (ISIS) to be the new caliphate, given that there is an ongoing debate about its Islamic character. However, if the present situation were analyzed according to perspective of earlier Islamic political theorist, the conclusions would be different.

Exploring Asad's thought would be helpful in defining a state's Islamic character, for he specified the relevant principles derived from the clear-cut political injunctions in the Qur'an and authentic Ahādīth. He believes in applying these principles peacefully to transform an existing state(s) into an Islamic one(s) and that the still ambiguous concept of an Islamic state has made setting one up impossible in the recent past. He tried hard to eradicate such confusion by his writings, interviews and public talks and dared to claim that there had never been a truly Islamic state after the four Rightly Guided Caliphs (Asad, 1961: v-vi) However, he maintains that such a state can become truly Islamic only via the conscious application of Islam's socio-political tenets to the nation's life and by incorporating those tenets in its basic constitution (Asad, 1961: 1). The following principles, he believes, could convert existing governments into Islamic include: (1) Sovereignty belongs to Almighty Allah alone (Ibid., 37ff), (2) Affairs to be transacted by mutual consultation (i.e., popular consent) (Ibid., 44ff), (3) the head of state must be reserved for Muslims only (Ibid, 40ff), and (4) No legislation can be totally or even partially repugnant to the Qur'an and Sunnah (Ibid., 35).

\section{Conclusion}

The concept of an Islamic state has been debated since Kemal Ataturk abolished the Ottoman Caliphate. Issues like Islam's compatibility vis-à-vis contemporary forms of government need to be contested in the light of Islam's basic sources and how Muslim political thinkers have understood the subject. The study of Muhammad Asad's thought, in comparison to others, is essential to deciding how an Islamic state can be set up in a peaceful manner. He considers an Islamic state to be a welfare state and holds that "a state 
can become truly Islamic only by virtue of a conscious and unreserved application of the socio-political tenets of Islam to the life of the nation; by an incorporation of those tenets in the basic constitution of the country." Islam forbids killing the innocent or other unjust activities that harm humanity. The spirit behind the application of Islamic punishments is to safeguard humanity.

Moreover, Asad purposely supported the cause of the Islamic state, which is endowed with flawless permanent and divinely ordained universal principles. His model of state revolves round two defining limits: (1) true sovereignty lies with Allah and that (2) Muslims must conduct all matters related to the state and the community through mutual consultation. Within this framework, Asad showed that an Islamic state is flexible enough to contain features of parliamentary, democratic and the rule of law, including the American institutions of presidency and the Supreme Court. For the betterment of humanity, the selection of the best option is important.

\section{References}

Ahmad, Dr. Israr. (2004). Lessons from the History: Reflections on the Past, Present, and Future of Two Muslim Communities. Lahore: Maktabha Khuddam al-Qur'ān.

Asad, Muḥammad. (1934). Islam at Crossroads. Gibraltar: Dār al Andalus.

Asad, Muhammad. (1954). Road to Makkah. New York, NY: Simon and Schuster.

Asad, Muhammad. (1961). The Principles of State and Government in Islam. Los Angeles, CA: University of California Press.

Asad, Muhammad. (1963). Islam and Politics. Geneva: Islamic Centre.

Asad, Muḥammad. (1980). The Message of the Qur'ān. Gibraltar: Dār al Andalus.

Asad, Muhammad. (1987). This Law of Ours and Other Essays. Gibraltar: Dar al Andalus.

Belkeziz, Abdelilah. (2009).The State in Contemporary Islamic Thought: A Historical Survey of the Major Muslim Political Thinkers of the Modern Era. London: I.B. Tauris \& Co., Ltd.

Binder, Leonard. (1963). Religion and Politics in Pakistan. Los Angeles: University of California Press.

Esposito, John L. (2001). Unholy War: Terror in the Name of Islam. New York, NY: Oxford University Press.

Esposito, John L. (Ed.). (2009). The Oxford Encyclopaedia of the Islamic World (OEIW). Oxford: Oxford University Press, vols. 1-5.

Fahad, Obaidullah. (2007). Islamic Shūrā: Religion, State and Democracy. New Delhi: Serials Publications.

Ghāzī, Hāmid al-Anșārī. (1956). Islām kā Nizām-e Hakūmat, trans. Delhi: al-Jamī’at Press.

Hasan, Pipip Ahmad Rifai. (1998). The Political Thought of Muhammad Asad. Canada: Concordia University Press. Maududi, Abul Ala. (1960). The Islamic Law and the Constitution. Lahore: Islamic Publications.

Ramadan, Tariq. (2004). Islam, the West and the Challenges of Modernity. Leicester, UK: The Islamic Foundation. Rosenthal, Ervin I. J. (1965). Islam in the Modern National State. Cambridge, UK: Cambridge University Press.

Shafi, Mufti Muhammad. (2008). Ma'ârif al-Qur'ān. Muhammad Shamim, trans. vols.1-8. New Delhi: Farid Book Depot.

Siddique, Kalim. (1983). Issues in Islamic Movement (1981-82). London: The Open Press Limited.

Siddique, Kalim. (1986). Issues in Islamic Movement (1984-85). London: The Open Press Limited. 